\title{
Elements of the Fourth Industrial Revolution in the Production of Wood Buildings
}

\author{
Jozef Švajlenka*, Mária Kozlovská
}

\begin{abstract}
We are on the threshold of a technological revolution that fundamentally changes the way we live, work and communicate with each other. To some extent, scale and complexity, this transformation will be as fundamental to humanity as no other technological change in the past. We do not know how it will evolve, but one thing is clear: the response to it must be integrated and comprehensive, involving all stakeholders on a global basis, from the public to the private sector, to the academic community and to civil society. In the context of sustainable and efficient construction, traditional material bases such as wood are becoming increasingly prevalent and implemented in modern design processes and design solutions. The great potential of this building material is achieved due to developments in production as well as the actual construction of timber buildings. Possible ways of production and construction of wooden buildings are diverse. Especially through prefabricated and solid wood products, which are also cross-glued laminated timber products, modern timber construction represents an interesting and sustainable construction technology. The aim of this paper is to define the basic aspects of industrial building industry in the context of new trends and to introduce the possibilities of implementation of elements of industry 4.0 in the field of wood-based construction.
\end{abstract}

Keywords: efficiency; Industry 4.0; modern methods of construction; sustainability; wood constructions

\section{INTRODUCTION}

In the world, market volatility is increasing, product life cycle is shortened, product complexity is growing, and global supply chains are increasingly influenced. In Western countries, productivity growth has declined sharply in recent years, at less than $1 \%$, and the share of developing countries in world industrial production has risen sharply to the detriment of developed countries. In this environment, companies strive to become more flexible, cheaper, faster and better responsive to business trends. Industry 4.0 provides solutions and ways for companies to meet these challenges [1]. Human society is on the verge of a technological revolution that fundamentally changes the way it will live, work and communicate with each other. The speed of recent discoveries is unprecedented. Compared to previous industrial revolutions (the first mechanized by steam discovery, the second brought electricity and mass production, the third used electronics and ICT to automate production), the fourth - known as Industry 4.0 - is developing at a much faster pace and affects every area of life. Industry 4.0 is built on two main pillars: digitalization (products, processes, services) and application of so-called exponential technologies that bring rapid growth in productivity and efficiency (ICT, 3D printing, sensoring, robotics, etc.). Continuously improved ICTs enable people, machines, devices, logistics systems and products themselves to communicate and collaborate directly $[2,3]$. This close interconnection of modern technologies enables to increase production efficiency $[4,5]$ by reducing all kinds of waste (costs, time, resources, etc.). However, the expected benefits must continue to take into account the sustainability principle. At the same time, smart and innovative production has to cope with energy, resource or environmental constraints in the context of social and economic impacts. The Industry 4.0 strategy line emerged in Germany in response to a decline in industrial production and productivity in paradoxically developed countries that expect it to increase global competitiveness [6]. This will not be possible without a strong innovation platform, which will bring, in addition to higher economic performance, undisputed benefits for the customer (respect for individual requirements - "Made-for-Me", "Customerization" as well as for the workers themselves, etc.) [7]. Although this modern technology line is directed to the so-called, the intelligent model of production, procurement or use of the product (Smart Factory, Smart Logistic, Smart Buildings, Smart Maintenance, etc.) is conditioned by a number of partial innovations, whether in the field of processes or the products themselves [8]. In the construction industry, one of the fundamental ways of increasing efficiency is the implementation of the Building Information Model (BIM) platform throughout its life cycle [9]. This revolutionary innovation in the management of a digitized building model follows the concept of the "Digital Twin", one of Industry 4.0 's core technologies [10]. The intelligent digital information model built in this way significantly supports subsequent "smart" innovations at all stages of the design, procurement or use of the construction. It follows that construction and building technologies are also responding much faster to global challenges in the field of sustainability of energy, resources, environment, but also intelligent design solutions [11] or better customization of provided services in the field of construction supply [12]. Modern technologies and methods in the construction industry are currently marked by the trend of sustainability and increasing productivity by new modern technologies or by innovation of traditional modern methods [13-15]. The term Modern Methods of Construction (MMC) is a common term for building technologies and off-site and innovative on-site technologies. Off-site construction methods use prefabricated elements made off-site and are then transported and assembled on site (prefabricated panel or modular systems, volumetric modules, etc.). On-site construction methods represent traditional construction systems, but in combination with innovative construction methods such as semi-finished construction methods, lost formwork, etc. According to several studies, MMCs are characterized by 
reduced construction time, greater productivity, better quality, lower costs, less waste, environmental emissions, reduced energy consumption, and higher occupational safety and health. MMCs enhance business efficiency and quality, customer satisfaction, sustainability and predictability of product delivery [16] and enable the management of the product process more effectively to deliver more quality products in less time [17]. Wood-based design solutions are increasingly being used within MMC [18, 19]. The aim of this paper is to define the basic aspects of industrial building industry in the context of new trends and to introduce the possibilities of implementation of elements of industry 4.0 in the field of wood-based construction.

\section{DEVELOPMENT OF BUILDINGS BASED ON WOOD}

Timber construction is characterized by a supporting structure made mainly of wood and wood-based materials. Wooden buildings can include not only buildings, but also hall buildings, footbridges, bridges, towers and the like. Buildings made of wood and wood-based materials find their greatest application in low-rise construction, usually on four above-ground floors. Structural systems can be divided into $\log$, skeleton and solid slab. By the first half of the 19th century, wooden constructions of residential buildings were built in two basic variants, with log and half-timbered walls. Both of these variants were characterized by demanding carpentry joints. Since the first half of the 19th century, sawn timber and machine-nails were added as joining elements. These technologies have enabled a lightweight skeleton made of boards and planks to be used in addition to log systems and heavy skeletons in the form of framed structures. In terms of implementation technology, this system has gradually evolved into three forms - construction site, panel and cellular. However, cells which exemplify a high degree of prefabrication have limited applications and are particularly suitable for the construction of temporary structures (for example, construction site equipment and the like). Currently, heavy and lightweight skeleton systems in various forms and prefabricated sandwich construction systems are most commonly used [20].

Wooden buildings made of prefabricated panels nowadays occupy the largest share of the wooden buildings market in Europe. There are hundreds of companies that produce panels of different sizes, different material composition and degree of completion. The diversity in panel technology is enormous. Upon detailed examination, however, we find that prefabricated panel timber buildings are based on three basic design principles of panels (wood frame panels, structural insulated panels SIPs, laminated wood panels). The oldest design principle, i.e. a panel with a wooden frame, was patented as early as 1880 . This year it celebrated 140 years of its existence. Panel buildings have become world famous right after their inception, and the winning mining of panel technologies across all continents continues for the third century. In the second half of the twentieth century, industrial production of prefabricated wooden buildings developed practically throughout Europe. Modern board construction materials, various types of thermal and acoustic insulation, modern connecting and construction fittings and, of course, building chemistry have been introduced to the market. The original Döcker panel with tapped and glued joints was increasingly replaced by a butt frame in the second half of the 20th century. The rigidity of such a panel is provided by a frame casing with a solid structural board, mostly based on wood. The different manufacturers differ in size of the panels produced, the degree of prefabrication, the degree of typing and the materials used. The basis of the panels, however, remains the wooden frame, which Johann Gerhard Clement Docker used in 1880 for his houses, and thus actually established a new branch of woodworking industry and construction. Currently, $60-65 \%$ of the construction is done in the USA. In Germany, Austria and Switzerland it is between 20 and $40 \%$ of construction. The largest number of constructions made of wood (including log buildings) is in Norway and it makes $95 \%$ of residential construction [21].

\section{IMPLEMENTATION OF PREFABRICATION IN THE FIELD OF WOODEN BUILDINGS}

The construction of wooden buildings as a division of the construction industry has moved from purely traditional craft on-site production techniques (on-site construction method) to industrial off-site prefabrication (off-site construction method) (Fig. 1, Fig. 2). In today's concept, prefabrication is usually understood as serial production of panel or modular construction. Precisely defined on the basis of literature, however, the term prefabrication refers to the creation of structural elements of a building in a place protected from the effects of the weather. The degree of off-site prefabrication varies, depending on whether only individual components or assembled elements or spatial modules are delivered on site. According to Kolb [22], prefabrication takes place although it is undemanding for all modern construction systems. Factory pre-fabrication gives construction companies the opportunity to make their productivity more efficient (Fig. 3, Fig. 4). At the same time, however, they must meet the requirements of customers, i.e. offer flexible building solutions, forcing them to strike a balance between productivity and flexibility to create more precise quality control. At present, it is irrelevant whether prefabrication is done by machine or by hand. The degree to which the individual elements are prefabricated is not further defined [23].

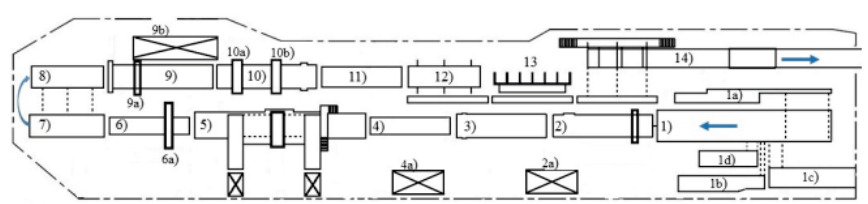

Figure 1 An example of an arrangement of a panel production line [23].

Wooden frame panels assembly line of Swedish company (Fig. 1):

Production line layout: 1) base frame assembly, 1a) horizontal components, 1b) vertical components, 1c) other parts, 1d) mineral wool insulation, 2) assembly of windsheets and installation grid, 2a) supplies for installation grid, 3) 
nailing installation grid, 4) manual placement of horizontal cladding wood elements, 4a) horizontal cladding stock, 5) nailing horizontal cladding 6) nailing horizontal cladding, 6a) nailing machine, 7) assembling from outside of panel, 8) tipping device 9) placement of vapor barrier and gypsum / wood-fiber boards, 9a) positioning device for boards, 9b) stock boards, 10) fastening and coupling device of gypsum / wood-fiber boards 10a) fixing machine, 10b) CNC router [23].

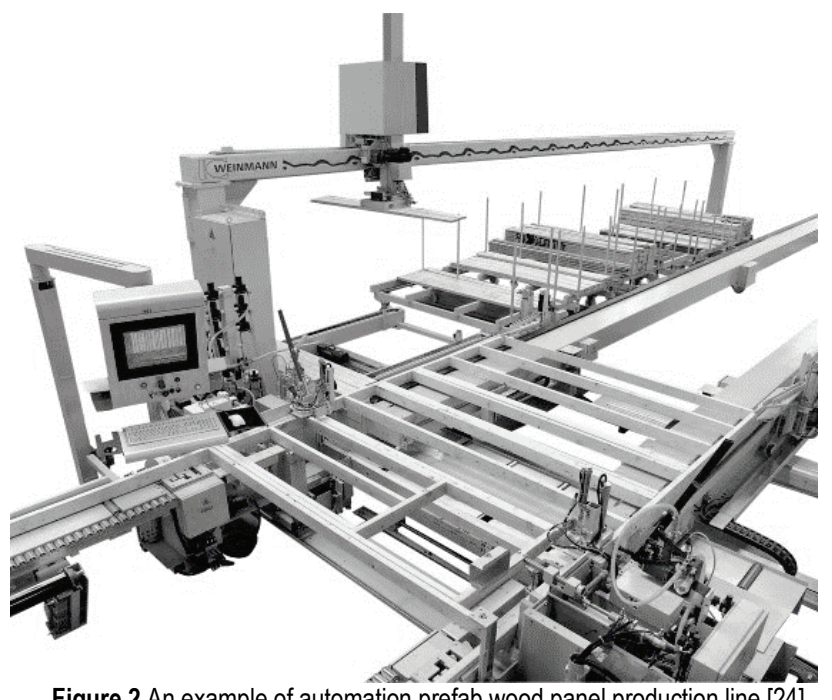

Figure 2 An example of automation prefab wood panel production line [24].

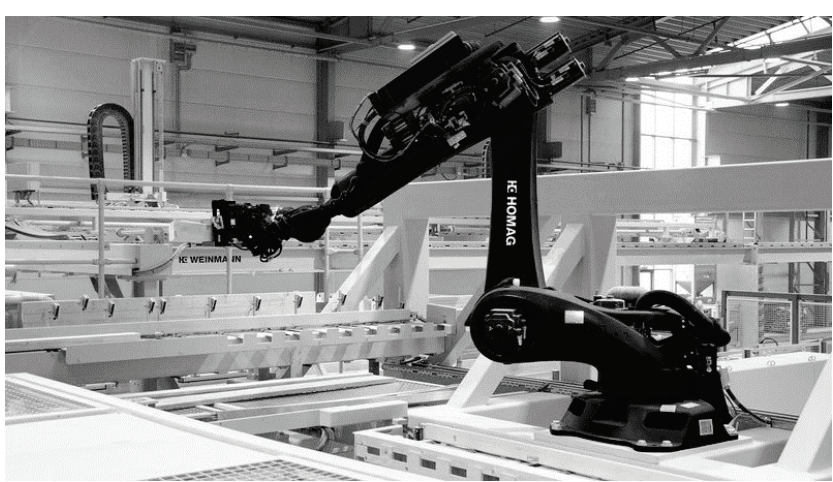

Figure 3 Robots used for manufacturing frame works in prefabricated housing construction [25].

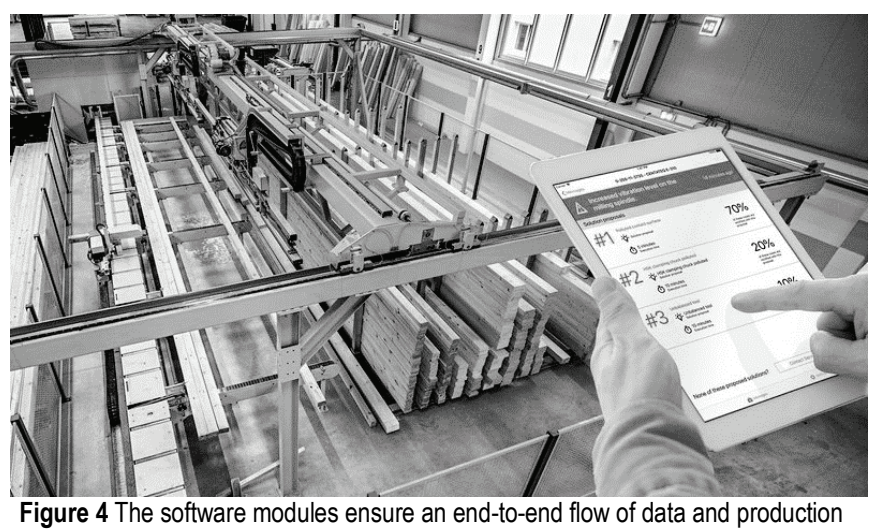

[25].
In wooden frame constructions, it is common to recognize the prefabrication stages depending on the number of elements assembled as follows:

- Fully assembled on site - on-site construction method,

- Open wall elements - the wooden frame is lined on one side, while the plate element fulfills the reinforcing function - so-called off-site method,

- Closed wall elements - the wooden frame is closed on both sides.

\section{CONCLUSION}

Like the revolutions that preceded the current trend, the Fourth Industrial Revolution has the potential to increase world income levels and improve the quality of life of populations around the world. New technologies and progress have brought fundamental changes for many countries. These trends and visions are also widely applied in the construction sector. Currently, all directions are focused on solutions that are efficient, sustainable and smart. In the implementation of efficient and sustainable solutions, woodbased industrial construction elements are well implemented as an efficient and environmentally friendly alternative. However, there are still gaps in the implementation of more efficient building practices and principles. In order to improve productivity in the timber sector, it is necessary to analyze and evaluate production and implementation processes in order to find more efficient processes as such. Elements of such analyses have also been described in this paper, which implies that by implementing modern computer-controlled automated production lines, conveyor systems and storage systems and many other aspects already mentioned, the trend of the Fourth Industrial Revolution can be taken.

\section{Acknowledgment}

VEGA project-1/0557/18 "Research and development of process and product innovations of modern methods of construction in the context of the Industry 4.0 principles".

\section{Notice}

The paper will be presented at PBE2020 - International Scientific Conference "People, Buildings and Environment 2020 ". The $14^{\text {th }}$ conference will be held in the Rožnov pod Radhoštěm city, the Czech Republic, from 7 to 9 October 2020. The paper will not be published anywhere else.

\section{REFERENCES}

[1] Industry4.sk (2020), SOVA Digital a.s. [cit. 2020-01-12]. Online: <http://industry4.sk/o-industry-4-0/co-je-industry-4$0 />$.

[2] Alaloul, W. S., Liew, M. S., Zawawi, N. A. W. A., \& Mohammed, B. S. (2018). Industry revolution IR 4.0: future opportunities and challenges in construction industry. In MATEC web of conferences (Vol. 203, p. 02010). EDP Sciences. https://doi.org/10.1051/matecconf/201820302010 
[3] Dallasega, P., Rauch, E., \& Linder, C. (2018). Industry 4.0 as an enabler of proximity for construction supply chains: A systematic literature review. Computers in Industry, 99, 205225. https://doi.org/10.1016/j.compind.2018.03.039

[4] Korytárová, J., Hanák, T., \& Lukele, P. E. (2017). Economic efficiency of brownfield regeneration: Study of South Moravian projects. Scientific Review Engineering and Environmental Sciences, 26(2), 151-158. https://doi.org/10.22630/PNIKS.2017.26.2.13

[5] Korytárová, J. \& Vaňková, L. (2017). Analysis of extreme values of the economic efficiency indicators of transport infrastructure projects. IOP Conference Series: Materials Science and Engineering. https://doi.org/10.1088/1757-899X/251/1/012043

[6] MacDougall, W. (2014). Industrie 4.0: Smart Manufacturing for the Future. Germany Trade \& Invest.

[7] Zawadzki, P. \& Żywicki, K. (2016). Smart product design and production control for effective mass customization in the Industry 4.0 concept. Management and Production Engineering Review, 7(3), 105-112. https://doi.org/10.1515/mper-2016-0030

[8] Lom, M., Pribyl, O., \& Svitek, M. (2016). Industry 4.0 as a part of smart cities. In 2016 Smart Cities Symposium Prague (SCSP) (pp. 1-6). IEEE. https://doi.org/10.1109/SCSP.2016.7501015

[9] Volk, R., Stengel, J., \& Schultmann, F. (2014). Building Information Modeling (BIM) for existing buildingsLiterature review and future needs. Automation in construction, 38, 109-127. https://doi.org/10.1016/j.autcon.2013.10.023

[10] Kaewunruen, S., Rungskunroch, P., \& Welsh, J. (2019). A digital-twin evaluation of net zero energy building for existing buildings. Sustainability, 11(1), 159. https://doi.org/10.3390/su11010159

[11] Antošová, N., Belániová, B., Chamulová, B., Janušová, K., \& Takács, J. (2019). The protection of environment during cleaning ETICS with biocides. Advances and Trends in Engineering Sciences and Technologies III-Proceedings of the $3^{\text {rd }}$ International Conference on Engineering Sciences and Technologies, ESaT 2018, pp. 281. https://doi.org/10.1201/9780429021596-44

[12] Gregorová, V., Ďubek, M., Duubek, S., \& Štefunková, Z. (2019). An experimental preparation of fibre concrete to software's detection of fibres. IOP Conference Series: Materials Science and Engineering. https://doi.org/10.1088/1757-899X/549/1/012018

[13] Hrdlicka, T. \& Cupal, M. (2019). Brick versus wood construction in residential. International Multidisciplinary Scientific GeoConference Surveying Geology and Mining Ecology Management, SGEM, pp. 395. https://doi.org/10.5593/sgem2019/6.2/S27.050

[14] Kaputa, V., Olšiaková, M., Mat’ová, H., \& Drličková, E. (2019). Do preferences for wood-framed houses' attributes change over time? Digitalisation and Circular Economy: Forestry and Forestry Based Industry Implications Proceedings of Scientific Papers, pp. 161.

[15] Gašparík, J., Szalayová, S., Alamro, B., \& Gašparík, M. (2019) Optimization method of elevator selection for the realization of construction processes. Advances and Trends in Engineering Sciences and Technologies III- Proceedings of the 3rd International Conference on Engineering Sciences and Technologies, ESaT 2018, pp. 369. https://doi.org/10.1201/9780429021596-58

[16] Zurich Insurance Group: Modern methods of construction, (ZIG) (2010). [cit. 2020-01-12]. Online: $<$ https://newsandviews.zurich.co.uk/wp-
content/uploads/2015/03/Modern-Methods-of-ConstructionGuide.pdf $>$.

[17] Doherty, T. (2007). Current practices and future potential in modern methods of construction, Modern methods of Construction (MMC) \& Eco - Building.

[18] Drozd, W. \& Leśniak, A. (2018) Ecological wall systems as an element of sustainable development-cost issues. Sustainability (Switzerland), 10(7). https://doi.org/10.3390/su10072234

[19] Matová, H. \& Kaputa, V. (2018). Attitudes of active and upcoming architects towards wood: The case study in Slovakia. Acta Facultatis Xylologiae, 60(2), 199-210.

[20] Kuklík, P. (2012). Minulost' a súčasnost' drevostavieb. [cit. 2019-12-17]. Online: <https://www.asb.sk/architektura/ rodinne-domy-architektura/drevostavby/minulost-asucasnostdrevostavieb>.

[21] Woodhouse, (2019). [cit. 2019-12-15]. Online: $<\mathrm{https}$ ://www.woodhouse.sk/historia-drevostavieb/>.

[22] Kolb, J. (2011). Dřevostavby: Systémy nosných konstrukci, obvodové pláště. Praha: Grada, pp. 320.

[23] Popovic, D. \& Winroth, M. (2016) Industrial timber house building - levels of automation, [cit. 2020-01-14]. Online: $<$ http://www.iaarc.org/publications/fulltext/ISARC2016Paper089.pdf $>$.

[24] AGACAD team, (2019). [cit. 2019-10-12]. Online: $<$ http://www.aga-cad.com/blog/new-possibilities-to-createbim-wood-framing-models-and-data-flow-for-automated-cadcam-production-lines-in-revit-environment>.

[25] HOMAG, (2019). [cit. 2020-01-08]. Online: $<$ https://www.homag.com/en/news-events/news/article/ automation-solutions-for-timber-construction>.

\section{Authors' contacts:}

Ing. Jozef Švajlenka*, PhD, MBA

(Corresponding author)

Technical University of Košice,

Faculty of Civil Engineering,

Department of Construction Technology, Economy and Management, Vysokoškolská 4, 04200 Košice, Slovakia

E-mail: jozef.svajlenka@tuke.sk

prof., Ing. Mária Kozlovská, PhD

Technical University of Košice,

Faculty of Civil Engineering,

Department of Construction Technology, Economy and Management,

Vysokoškolská 4, 04200 Košice, Slovakia

E-mail: maria.kozlovska@tuke.sk 